\title{
Giving Birth to a Male Specialist Obstetrician According to Perspective of Islamic Law
}

\author{
Husnaini ${ }^{1}$, Zulhamdi ${ }^{2}$, Muhammad Diah ${ }^{3}$ \\ ${ }^{1}$ Department of Constitutional Law, Sharia Faculty, State Islamic Institute of Lhokseumawe, Aceh, \\ Indonesia \\ 2 Department of Sharia Economic Law, Sharia Faculty, State Islamic Institute of Lhokseumawe, Aceh, \\ Indonesia \\ ${ }^{3}$ Islamic Department of Family Law, Sharia Faculty, State Islamic Institute of Lhokseumawe, Aceh, \\ Indonesia \\ Email: zoel_hamdi@yahoo.co.id
}

\begin{abstract}
:
Women in giving birth still go to the specialist obstetrician when there is a recommendation from the midwife, or the patient comes directly to the obstetrician, the patient no longer chooses or sorts a male or female obstetrician, in the view of the community as if there are no legal issues. Though the proposition of al-Quran and hadith has ordered us to hold our gaze and preserve the genitals of both men and women, to see the aurat (private parts, those parts of the body that cannot be exposed or should be covered according to Islam) which the same sex is still not allowed, much less in different sex. Especially with regard to giving birth that shows all organs including aurat which is very vital, and also explained by the perspective of figh ulema who have very strict rules in seeing aurat, even in the case of medical treatment, especially treatment to the doctor in different sex of patient. Likewise with the results of the plenary session- $V$ which explains male patients are not justified to treated by female medical, and vice versa, moreover women giving birth to a male obstetrician is even more not allowed, this is under normal conditions, as for emergency conditions is allowed but still under very strict requirements. So it can be concluded that Islamic law does not allow giving birth to male obstetricians (in normal conditions), except in emergency situations where there is no other choice or in areas where there are no female obstetricians. The Aceh Ulema Consultative Assembly in the results of the ulema's plenary session on the use of defiled drugs and medical services by different sex in the Islamic perspective. With provisions, if only general treatment that does not lead to seeing vital organs in women is prohibited, much less giving birth which is clearly a male doctor looking openly and transparently and touching vital organs in female patients, then it is very not allowed in Islam, except there is no other choice.
\end{abstract}

Keywords :

Islamic law; giving birth; male obstetrician.

\section{Introduction}

The phenomenon that occurs in the midst of society nowadays, especially for women who want to give birth, still go to a specialist obstetrician when there is a recommendation from a midwife, or the patient no longer chooses or sorts a male or female obstetrician, in the view of the community as if there are no legal issues. And this is under normal conditions not emergency conditions (ikhtiari conditions). In this case the male obstetrician do not feel reluctant (as if Islamic law has legalized) to deal with pregnant women. This has become academic anxiety.

Whereas The Aceh Ulema Consultative Assembly (MPU) has issued a fatwa in the plenary session -V with the theme "The Use of Defiled Drugs and Medical Services by Different Sex in the Islamic Perspective" in the fatwa explained that male patients were handled by male specialists and women patients are handled by women specialists in an ikhtiari condition, whereas in 
emergency conditions the male patients are justified to treated by female medical, and vice versa, it is in a very urgent and inevitable condition (there is no other choice)

Even though in the Qur'an Surah An-Nur 30-31 is clearly Allah says that: "Tell the believing men to reduce [some] of their vision and guard their private parts. That is purer for them. Indeed, Allah is acquainted with what they do (30). And tell the believing women to reduce [some] of their vision and guard their private parts and not expose their adornment except that which [necessarily] appears thereof ... (31)".

And also the Messenger of Allah said which means that "A men must not see the aurat of another men, likewise woman must not see the aurat of another woman, and also man are not together with one clothes in other men, and so also women are not together with one clothes in other woman".

Based on the proposition mentioned above it seems clear that same-sex persons are prohibited from seeing or displaying their aurat, The mafbum muwafaqahnya is the opposite sex, moreover it is forbidden to show the aurat. The problem arises how pregnant women giving birth to male specialist obstetricians in terms of Islamic law and when looking at the aurat of female patients in labor.

\section{Review of Literature}

\subsection{The Concept of Aurat in Islam}

Aurat is an absorption word from Arabic which comes from the word "ara yauru-auran" which means looked, born, appeared. This word can also mean disgrace, it can also mean means to hoard with the ground until the spring is blocked. This means that aurat is something that must be covered and hoarded so that it cannot be seen. The word that means aurat also exists in the word "sauah" as stated in the QS. Thaha verse 20: 121 which means: "And Adam and his wife ate of it, and their private parts became apparent to them, and they began to fasten over themselves from the leaves of Paradise. And Adam disobeyed his Lord and erred".

In terms aurat is something that invites the lust, arises lust of anger, while the aurat has an honor that brought by shame so that it is covered and nurtured by not disturbing other humans, and causing wrath, even though the peace of life and peace should be best kept the good.

In the view of Islamic legal experts, aurat are parts of the human body which in principle should not be seen, except in emergencies or urgent conditions. Rasulullah SAW also said which means "Surely a daughter if she has menstruation (baligh), must not be seen from her except her face and hands up to the wrist" (HR Abu Dawud). These propositions clearly show that a woman's entire body is aurat, except for her face and palms. It also clearly shows that a woman is obliged to cover her aurat that are covering her entire body, except her face and palms.

\section{a. Ulema's Perspective of the Woman Aurat}

The ulema are still debating about the aurat that women must cover when they meet and interact with men. Below will be explained a little opinion of ulema about woman aurat.

a) Opinion of Al-Ahnaf (Hanafi follower) believes that women may open their faces and palms but men are still forbidden to look at her with a lust,

b) In the mazhab of Maliki there are three opinions:

1) Telling that must cover the face and palms. 
2) It is not required to cover her face and palms, but men must keep their eyes down.

3) The difference between being beautiful and not being beautiful of a woman, if she is beautiful, she must cover her face and palms. While women who are not beautiful is not required to close it or be laid down.

c) Jumbur (largest group): mąhab of Shafi'i says it is not compulsory to cover the face and palms even though they are devoted to cover it up.

d) Mazhab of Hambali: says it is mandatory to close both.

e) Jumhur Fuqaha (the largest group of fiqh experts) argues that the face and two palms are not aurat because they are not obliged to close but must be closed if deemed unsafe.

From some of the opinions of the mazhab ulema above can take the common thread that most of them argue that the woman aurat which must be covered are the whole body except the face and palms only.

\section{b. Factors that Allow Viewing Aurat}

Islam views the relationship between men and women as a very important thing. But nevertheless, Islam has established general law regarding this issue. Islam actually pays attention to seeing the goal or goodness that is to be realized, or the dangers that are possible, the description and the requirements that must be met or others. The best clues in this matter are the guidance of the Prophet and the guidance of the Companions that become guidelines. People who want to heed this guidance, will undoubtedly know that Islam does not imprison women or isolate them as was the case of the decline of Islam. ${ }^{1}$

Basically, QS. An-Nur (24): 31 does not provide a strict limit on which aurat women may be seen in front of the unbeliever women. It's just that a Muslim woman must maintain her honor by not opening taboo aurat (such as breasts, genitals, thighs, etc.) in the presence of unbeliever women. Let her dress modestly and not demean herself.

\subsection{Results of Plenary Session-V of the Aceh Ulema Consultative Assembly, Regarding Treatment to the Doctor with Different Sex}

As for the Results of the Plenary Session - V on 10 to 12 October 2017 the Aceh Ulema Consultative Assembly, the theme is the use of defiled drugs and medical services by different sex in the Islamic perspective ${ }^{2}$ :

Part One explains the use of defiled drugs. Part Two explains the medical services by different sex: the content is male patients can only be served by male medical and female patients are served by female medical, in normal conditions, means that there are male and female medical.

But in emergency conditions, for example there is female patient who suddenly need to be dealt with quickly but there is only medical experts male or vice versa, there are only female medical, then in such conditions, female medical personnel can handle male patients, in accordance with the hadith of Bukhari History From Rubai'ah bt Muawwiz, Umdatul Qari, j.5 p. 80. And also the hadith of Muslim history, from Umm Athiyah Al-Anshariah, Syarhul Ma'aanil Atsaar, j. Pg. 178.

This ability is certainly with a number of conditions including:

1. There is no female doctor on par with the male doctor.

\footnotetext{
${ }^{1}$ Yusuf Qardhawi, Fatwa-Fatwa Kontemporer (Jakarta: Gema Insani, 2006).

${ }^{2}$ Majelis Permusyawaratan Ulama Aceh, Himpunan Bahan ...p. 64. 
2. The patient's urgent situation must be quickly helped because if not immediately, the disease will spread and endanger his life.

3. Doctors should not open any part of the body (aurat) of the female patient, except to the extent required in the treatment.

4. The doctor is a Muslim known by his piety.

5. Must be accompanied by one of the mahram, or her husband, or another Muslim woman.

So the results of the session above explain that it is not justified for male patients to be treated by medical women and also vice versa, under normal conditions, while under emergency conditions are allowed but still under very strict requirements, which clearly are not the same as the reality in Aceh which is currently being implemented in Islamic law.

\section{Discussion}

\subsection{Islamic Law Perspective on Giving Birth to a Male Specialist Obstetrician a. Al-Qur'an}

Based on the nash that are qabt'i namely the sentence of Allah in verse An-nur: 30-31

Meaning: 30. Tell the believing men to reduce [some] of their vision and guard their private parts. That is purer for them. Indeed, Allah is acquainted with what they do. 31. And tell the believing women to reduce [some] of their vision and guard their private parts and not expose their adornment except that which [necessarily] appears thereof and to wrap [a portion of] their head covers over their chests and not expose their adornment except to their husbands, their fathers, their husbands' fathers, their sons, their husbands' sons, their brothers, their brothers' sons, their sisters' sons, their women, that which their right hands possess, or those male attendants having no physical desire, or children who are not yet aware of the private aspects of women. And let them not stamp their feet to make known what they conceal of their adornment. And turn to Allah in repentance, all of you, $\mathrm{O}$ believers that you might succeed.

\section{b. The hadith}

Hadith for Muslims is an important thing because in it revealed various traditions that developed during the time of the Prophet. Traditions that lived during the prophetic period refer to the person of the Prophet, as a messenger of Allah SWT. In it the conditions for various Islamic teachings, therefore, sustainability continues to run and develop until now along with human needs. The continuation of the tradition is so that humanity today can understand, record and implement guidance on Islamic teachings that are in accordance with what the Prophet Muhammad exemplified (Faisal, et al, 2019).

The Messenger of Allah said that means "A men must not see the aurat of another men, likewise woman must not see the aurat of another woman, and also man are not together with one clothes in other men, and so also women are not together with one clothes in other woman".

Based on the arguments mentioned above, namely the Qur'an and the Hadith, the Sharia instructs us to hold our gaze and maintain the genitals of both men and women, same-sex persons are prohibited from seeing or displaying their aurat, the opposite sex is also forbidden. Especially with regard to vital organs.

\section{c. Perspective of Fiqh Ulema}

Within certain restrictions, the ulema allow a doctor or paramedics to treat patients who are not their mahram if there is no doctor who are their mabram. Ibn Abidin said: In the book AlJauharah stated: "If the disease attacks the entire body of the woman, the doctor may see it during 
treatment, except for vital genitals. Because it is an emergency. If the place that hurts is pubic, then another woman should be taught to treat it. If there is no, while the safety of her soul was very worrying or feared that she would be afflicted with an illness she could not bear, then they should cover her entire body except the diseased place (the genitals) and then the doctor is invited to treat it while still holding the gaze as best he can except for the part being treated".

Likewise, it is permissible for nurses to help their ablution even though one is being cared for by a woman. Muhammad Fu'ad said: Among the propositions which show that men may treat women with the limitations mentioned earlier is a hadith narrated by Imam Al-Bukhari of ArRubayyi 'bint Mu'awwidhia said: "We once fought with the Prophet sallallaahu 'alaihi wa sallam. Our job is to provide drinking water and help troops, and bring the dead and wounded troops to Medina".

Imam Al-Hafidz Ibn Hajar Al-Asqalani said: "The law that permit men treat women is taken by implicitly. Imam Al-Bukhari did not affirm the law because there was still a possibility of it happening before the revelation of the verse which ordered the hijab. Or each woman at that time only treated her husband or mahram only. In the general law: women may treat men in times of emergency, and must be limited as needed especially with regard to seeing and holding patients.

In essence there are similarities in the perspective of the ulama, it is permissible to see any part of the patient's body for medicinal purposes, and to avoid slander, and it is advisable to be accompanied by a mahram or a trusted person. 'Illat prohibition because it will invite slander, or will occur adultery, is a preventive effort (sad al-dzari'at). Based on the fiqhiyyat rule that prohibiting because of sad al-drari'at is allowed for benefit.

Khatib Al-Syarbini, stated: Explanation about the forbidden to see and touch (the opposite sex) if there is no need. If necessary, then seeing and touching it can be done like fashad ${ }^{\beta}$, cupping, and treatment even though on the genitals because of urgent needs and so on. Because in the forbidden there is sin, then men can treat women and vice versa with the requirement that must be accompanied with their mahram, or husband ... And it requires that there is no women to treat fellow women and vice versa. If to treat women that are only non-Muslim women and Muslim men, then as Al-Adzra'i said, female doctors / nurses take precedence because the gaze and touches of women (in female patients) are lighter than men. Adzra'i said: Seeing a woman's face and palms is only for necessity. Seeing other than the face and palms of women (other than genitals) because of greater needs ... and seeing genitals is permissible because of even greater needs. Therefore, opening the genitals because emergencies are not considered damaging muru'ah (self-esteem) as quoted by Imam Ghazali.

Al-Khatib Al-Syarbini, said that if it is forbidden to see, it is forbidden to touch because touch is stronger inviting lust. However, if in an emergency or urgent need the male doctor touches the female patient or the female doctor holding the male patient is allowed as needed. If the touch is made with the gloves, then no touch is allowed. Imam Badruddin Al-Zarkasyi in Al-Mantsur fil Qawaid Al-Fiqhiyah said: Al-Qaffal said in Al-Fatawa, "Women when treated with fashad by nonmahram men when not accompanied by another woman or a mahram, she cannot open her entire arm. She is obliged to cover her hands with a cloth and not to open them except members who must be opened for fashad treatment, if more than that, then he sins against God.

Ibn Muflih in Al-Adab Al-Syar'iyah, page 2/429 states: If a woman is sick, and no one can

\footnotetext{
${ }^{3}$ Fashad is a type of traditional medicine by removing blood from wounds to remove toxins and the like.
} 
treat except men, then it is permissible for the man to see what needs to be seen including seeing the genitals. So do men with men. Ibn Hamdan said: If there is no one who can treat (a man) except a woman, then that woman may see what needs to be seen including his genitals.

Likewise the perspective of Al-Qadhi Abu Ya'la is this: it is permissible for doctors (men) to see women to their aurat if needed as is the opinion of Imam Ahmad bin Hanbal in Al-Maruzi's history. Likewise, it is also permissible for female doctors (seeing male patients) ${ }^{4}$. All the perspective of the figh ulema mentioned above, have very strict rules in seeing aurat, even in the case of medical treatment, let alone treatment in different sex.

\section{d. Number of Specialist Obstetrician in Aceh}

The number of specialist obstetricians both men and women in Aceh, although not yet sufficient, but it is sufficient to seek treatment in an endeavor (normal). Because the number of male obstetricians are 37 and women are 22, except in certain regions where there are no obstetricians who are female, even there is an opinion that if there are no female specialists required to seek treatment to other areas even if they are not a domicile, unless it is very urgent because they want to save the lives of the baby and its mother.

Based on the verse, hadith, fiqh ulema' thoughts, and the number of obstetricians in Aceh Province, the researchers concluded that Islamic law does not justify women giving birth to obstetricians who are male in normal conditions (ikhtiari). So for today's conditions in Aceh it is time for women to give birth to obstetricians who are female sex, because in perspective of Islamic law it is not permissible for women to give birth to obstetricians who are male, because it involves seeing very vital organs by a non-husband. Except in emergency conditions or certain areas where there is no other solution except to be handled by male obstetricians in order to save the lives of the baby or the mother, and even then with very strict conditions, among others there must be a mahram, then cover the whole body except those treated, and the doctor is Islam, put in trust, and in accordance with the code of ethics of medicine.

\section{e. Perspective of Aceh MPU Ulema on the Law of Women Giving Birth to Male Specialist Obstetricians}

A Muslim woman is obliged to maintain her honor, so she must maintain the shame that has become a woman's nature, avoiding the hands of men who are not mahram, distancing herself from ikbtilath ${ }^{5}$.

In emergency conditions ${ }^{6}$ (there are no female obstetricians) it is permissible for women to give birth to obstetricians who are male, but it requires that they must meet religious requirements, accompanied by mahram, with certain restrictions (seeing female aurat is just a medical necessity) and can distinguish feeling with his profession as a doctor?

\footnotetext{
${ }^{4}$ Sayid Sabiq, Fiqhus Sunnah, p. 1/34.

${ }^{5}$ It is a man and a woman together in a quiet place. In this case it involves the association of fellow human beings, whose signs have received high attention in Islam. That is related to the teachings of Islam which highly upholds safety for humans from all distractions. Moreover, in problems mu'amalah (association) with other types. In Islam, the relationship between men and women has been arranged with boundaries, to fortify the slanderous turmoil that endangers and disrupts life. Therefore, Islam has banned associations that are filled with ikhtilat (mixed mix between men and women).

${ }^{6}$ Meaning of Dharuriat here in addition to the meaning of emergence in general terms, the author also added the definition of emergence here is that there are no obstetricians who are female or midwives in the region who can handle labor.

7 Interview with Tgk. H. Helmi Imran, Member of the MPU Fatwa Commission in Aceh Province.
} 
It should not be treated by doctors of different sex, that is to say, men should not seek treatment for women and vice versa, under normal conditions, except in conditions of emergency and even then accompanied by very strict requirements. So if treatment at different sex is not allowed let alone give birth to women that are open or reveal a very vital organ in front of doctors who are male (not her husband) then it is absolutely not permitted, unless there is no other solution.

The woman must seek medical treatment for women, and men seek medical treatment for men, so men should not seek treatment for women and women should not seek treatment for men. Except for the disease that afflicts the woman, no medical woman can handle it. Vice versa, so if treatment is not allowed on different sex of medical, let alone giving birth which is open to vital organs in the face of men who are not her husband, then it is absolutely not allowed. Except for emergency or in areas where there are absolutely no medical women ${ }^{8}$.

The results of the MPU plenary session-V of Aceh Province on 10 to 12 October 2017 with the theme is The Use of Defiled Drugs and Medical Services by Different Sex in the Islamic Perspective, in the fatwa explained that male patients were handled by male specialists and woman patients handled by women specialists in the condition of endeavor, while in emergency conditions women are allowed to seek treatment from male specialists and vice versa, it is in a very urgent and inevitable condition (there is no other choice) $)^{9}$.

Based on interviews with several MPU ulema in Aceh Province and the results of plenary session of MPU Ulema regarding treatment with different sex, it can be concluded that treatment at different sex is not permitted under normal conditions (ikhtiari) while treatment at emergency conditions is permitted as long as there is no other choice.

So according to the analysis of researchers, if treatment is not focused on looking at organs that are very vital, especially the nature of giving birth which reveals openly a very vital organ in front of men who are not her husband is absolutely not allowed (under normal conditions), even though The MPU in the Aceh province does not specifically discuss the law of giving birth to male obstetricians, but if we look at the law that is discussed about treatment in different sex it is also a very strong reason for us to take the law of giving birth to male obstetricians that is not allowed.

\section{Conclusion}

Islamic law does not allow treatment in the opposite sex under normal conditions (ikhtiar), except in emergency conditions, and even then it is tightened with the conditions that have been determined in Islam and medical ethics. So giving birth to a male obstetrician in normal conditions is not permitted except in emergencies where there is no other choice or in areas where there are no female obstetricians.

The Aceh MPU did not specifically discuss the law of giving birth to specialists whose doctors were male, but the Aceh MPU has produced a plenary session of Ulema about the use of defiled drugs and medical services by different sex in the Islamic perspective. With the provisions, the law does not allow treatment in the opposite sex under normal conditions, except in emergency conditions. Then with this, we can use the analogy of qiyas aulawi ${ }^{10}$, said one of the members of the

\footnotetext{
${ }^{8}$ Interview with Tgk. H. Hamdani, S. Sos. I, Member of the MPU Commission C in Aceh Provincial.

${ }^{9}$ Interview with Tgk. H. Zulkarnain Juned, Member of the MPU Commission C in Aceh Province.

${ }^{10}$ qiyas aulawi is a legal illat given to ash/ more strongly given to furu'.
} 
MPU in Aceh province, Tgk. H. Zulkarnain Juned, if only general treatment that does not lead to seeing vital organs in women is prohibited, much less giving birth which is clearly a male doctor looking openly and transparently and touching vital organs in female patients, then it is very not allowed in Islam, except there is no other choice.

\section{References}

Abdurrahman, bin Abi, B., A., S. Al-Asybah Wa an_Nazqair, Bairut: Dar Al-Kutub Al-Ilmiyah. Aceh Ulema Consultative Assembly. (2017). Himpunan Bahan Keputusan/Hasil Sidang "Penggunaan Obat Bernajis dan Pelayanan Medis Oleh yang Berlainan Jenis Dalam Pandanggan Islam".

An-Nabhani, T. (2007). Sistem Pergaulan Dalam Islam. Jakarta: Hizbut Tahrir Indonesia.

Fahruddin, F., M. (1984). Aurat dan Jilbab dalam Pandangan Islam. Jakarta: CV. Pedoman Ilmu Jaya,

Faisal, A., Wahid, R. A., and Sulidar. (2019). Study of Hadith Living in All Islamic Boarding Schools in Medan, Indonesia. Budapest International Research and Critics Institute. Vol. 2 No. 2 Pp. 195-208

Fauzi, A. (2016). Pakaian Wanita Muslimah Dalam Perspektif Hukum Islam, Iqtishodia Jurnal Ekonomi Syariah, Vol. 1, No.1.

Fitria, R., (2012). Batas Aurat Muslimah dalam Pandangan al-Albaniy. Journal. Padang: Imam Bonjol State Islamic Institute (IAIN), Vol. 8, No. 2.

Hakim, L. (2008). Tinjanan Hukum Islam Terbadap Mekanisme Kerja Dokter Abli Kandungan Laki-Laki Dalam Menangani Ibu Hamil Dan Melabirkan Di PKU Muhammadiyah Yogyakarta, Thesis. Yogyakarta: Al-Ahwal Asy-Syakhsiyyah Department, Sharia Faculty, Sunan Kali Jaga State Islamic University.

Hathout, H. (1994). Revolusi Seksual Perempuan. Obstetri dan Ginekologi dalam Tinjauan Hukum Islam. Bandung: Mizan.

Haya, binti Al-Barik, M. (1422H). Ensiklopedi Wanita Muslimah, terj. Amir Hamzah Fachrudin. Jakarta: Darul Falah.

Kisyik, A., H. (1992). Bimbingan Islam untuk Mencapai Keluarga Sakinah, alih bahasa Ida Mursida. Bandung: Mizan.

Khalaf. A., W. (1978). Imu Ushul al-Fiqh Cairo: Dar al-Qalam.

Lumenta, B. (1989). Pelayanan Medis, Citra, Konflik dan Harapan. Tinjauan Fenomena Sosial, Yogyakarta: Kanisius.

Mu'alifin (2014), Konsep Menutup Aurat Dalam Al-Qur'an Surat Al-Nür Ayat 30-31 Dan Implementasinya Dalam Pendidikan Islam, Thesis. Semarang: Faculty of Tarbiyah and Teacher Training at the Walisongo State Islamic Institute

Mulawarman, H. (2014). Profesi Dokter Kandungan Laki - Laki Dalam Perspektif Hukum Islam, Jurnal Penelitian Keislaman, Vol. 10, No. 2, Jakarta: Sekolah Pascasarjana UIN Syarif Hidayatullah,

Munawir, A., W. (1997). Kamus Al-Munawir Surabaya: Pustaka Progresif.

Pratiknya, A., W., Salam, A., and Sufro, M. (1986). Islam Etika dan Kesebatan. Sumbangan Islam dalam Menghadapi Problem Kesehatan Indonesia Tabun 2000-an Jakarta: CV. Rajawali.

Qardhawi, Y. (2006). Fatwa-Fatwa Kontemporer, Jakarta: Gema Insani.

Rahmawati, S. (2012). Tinjauan Hukum Islam terhadap Pemeriksaan Kandungan oleb Dokter Abli Kandungan Laki-laki. Thesis: Islamic Law Study Program FIAI UII.

Rasyidah. (2017). Dakwah Struktural Pakaian Muslimah Di Kelantan - Malaysia. Jurnal Takammul (Pusat Studi Wanita UIN Ar-Raniry Banda Aceh, Vol. 6 No. 1.

Sahih Muslim. (1981). "Kita al-Haid": Dar al-Fikr. IV: 30 Hadith/No. 209.

Salam, B. (2014). Pandangan Hukum Islam Terhadap Dokter Abli Kandungan Laki-Laki Yang Menangani Ibu Hamil Dan Melabirkan Di Kota Bengkulu Di Kaitkan Dengan Uu No 29 Tabun 2004 Tentang Peraktek Kedokteran, Thesis: Unpublished.

Shihab, Q. (2004). Jilbab Pakaian Muslimah, Jakarta: 1 Lentera Hati. 